\title{
Degradation of Escherichia coli Chromosomal and Plasmid DNA in Serum
}

\author{
By MAJA ROZENBERG-ARSKA, ${ }^{1,2 *}$ ELS C. SALTERS, ${ }^{2}$ JOS A. VAN \\ STRIJP, ${ }^{2}$ WIEL P. M. HOEKSTRA ${ }^{3}$ AND JAN VERHOEF ${ }^{1,2}$ \\ ${ }^{1}$ Department of Clinical Bacteriology, University Hospital, Catharijnesingel 101, Utrecht, \\ The Netherlands \\ ${ }^{2}$ Department of Microbiology, State University of Utrecht, Catharijnesingel 59, Utrecht, \\ The Netherlands \\ ${ }^{3}$ Department of Molecular Cell Biology, State University of Utrecht, Padualaan 8, Utrecht, \\ The Netherlands
}

(Received 22 July 1983)

\begin{abstract}
Incubation of serum-sensitive $\left[{ }^{3} \mathrm{H}\right]$ thymidine labelled Escherichia coli $\mathrm{PC} 2166$ (RSF1030) and $E$. coli AM1281(pBR322) harbouring small plasmids (mol. wt $5.5 \times 10^{6}$ and $2.6 \times 10^{6}$ ) in serum resulted in killing of $99.9 \%$ of the bacteria within $15 \mathrm{~min}$ and in the release of $85 \%$ of the radioactivity into the medium after $1 \mathrm{~h}$ incubation. The fate of chromosomal and plasmid DNA during incubation of the bacteria in serum was analysed by measurement of the amount of DNA-associated radioactivity, by TCA precipitation, by agarose gel electrophoresis and by the capacity of DNA to transform competent acceptor bacteria. Chromosomal DNA and high molecular weight plasmid DNA were rapidly degraded after $1 \mathrm{~h}$ incubation of bacteria in serum. However, low molecular weight plasmid DNA was virtually unaffected and remained physicochemically as well as biologically intact during up to $4 \mathrm{~h}$ of incubation of bacteria in serum.
\end{abstract}

\section{INTRODUCTION}

Many Gram-negative micro-organisms are serum sensitive. The bactericidal function of serum depends upon the activation of the terminal components of the complement system (Frank, 1979). The membrane attack mechanism of the complement system (C5-C9) damages the bacterial cell wall and cell membrane (Frank, 1979) resulting in the loss of permeability due to the breakdown of peptidoglycan by lysozyme (Glynn, 1969; Spitznagel \& Wilson, 1966). Shortly after these initial events, crucial metabolic changes occur in the bacterial cell. Firstly, RNA metabolism and protein synthesis are affected leading to rapid loss of the ability of the bacterium to synthesize enzymes (Feingold $e t$ al., 1968a, $b$; Melching \& Vas, 1971). A few minutes later, cessation of DNA replication occurs and lipid synthesis is abruptly halted after 25 to $30 \mathrm{~min}$ incubation in serum. The loss of the permeability control leads to leakage of low molecular weight substances and spillage of ribosomes. Significant breakdown of bacterial components following complement induced bacteriolysis has been detected using a number of bacterial species (Bladen et al., 1966; Feingold et al., 1968b; Friedlander, 1975; Melching \& Vas, 1971 ; Spitznagel \& Wilson, 1966). But the exact sequence of events which lead to bacterial killing and degradation by serum remains unknown. It is reasonable to assume that during the process of serum bacteriolysis irreversible bacterial cell injury with concomitant degradation of bacterial DNA occurs. An investigation was therefore undertaken to determine the fate of chromosomal and plasmid DNA following incubation of a serum sensitive Escherichia coli strain in serum. In contrast to a rapid degradation of chromosomal and large plasmid DNA, virtually no degradation of small plasmid DNA was observed during incubation of $E$. coli in serum. 


\section{METHODS}

Bacteria. The serum-sensitive Escherichia coli K12 strain PC2166(RSF1030) harbouring a plasmid coding for ampicillin (mol. wt $5.5 \times 10^{6}$ ), E. coli K12 strain PC2166(R144) harbouring a kanamycin-resistant conjugative plasmid (mol. wt $65 \times 10^{6}$ ), E. coli K12 strain AM1281(pBR322) harbouring a plasmid coding for chloramphenicol and tetracycline resistance (mol. wt $2.6 \times 10^{6}$ ) were used. Escherichia coli K12 C600 was used as an acceptor strain for plasmid DNA and $E$. coli AM1095 as an acceptor strain for chromosomal DNA.

Radioactive labelling. Escherichia coli PC2166(RSF1030), AM1281(pBR322) and PC2166(R144) were inoculated from a blood-agar plate into $5 \mathrm{ml}$ Mueller-Hinton broth (Difco), containing $0.02 \mathrm{mCi}\left[\right.$ methyl- ${ }^{3} \mathrm{H}$ ] thymidine (specific activity $5 \mathrm{Ci} \mathrm{mmol}^{-1}, 185 \mathrm{GBq} \mathrm{mmol}^{-1}$; Amersham) and $1.25 \mathrm{mg}$ of deoxyadenosine (BDH). After $18 \mathrm{~h}$ incubation at $37^{\circ} \mathrm{C}$ the bacteria were washed three times with $\mathrm{PBS}$ pH 7.4 and adjusted to a final concentration of $10^{9}$ c.f.u. $\mathrm{ml}^{-1}$ using a colorimeter at $650 \mathrm{~nm}$ confirmed by pour plate colony counts.

Serum. Serum from healthy donors was pooled and stored in small portions at $-70^{\circ} \mathrm{C}$. Serum was thawed shortly before use and diluted to the final concentration of $20 \%(\mathrm{v} / \mathrm{v})$ in Hank's Balanced Salt Solution containing $0 \cdot 1 \%$ gelatin.

Serum bactericidal and bacteriolytic activity. Serum bacteriolytic activity was measured by the method described by Friedlander (1975). In polystyrol tubes $1 \mathrm{ml}$ radiolabelled bacteria $\left(10^{9}\right.$ c.f.u. $\left.\mathrm{ml}^{-1}\right)$ was mixed with $4 \mathrm{ml} 20 \%$ $(v / v)$ human pooled serum and incubated at $37^{\circ} \mathrm{C}$. After $0,15,30,60,120$, and $240 \mathrm{~min}$ incubation, tubes were removed from the water bath and placed in ice. After centrifugation at $12000 \mathrm{~g}$ for $10 \mathrm{~min}$, the radioactivity in the sediment and in $100 \mu \mathrm{l}$ of the supernate was measured in a liquid scintillation counter (Mark II Nuclear Chicago, Ill., USA) after addition of $2.5 \mathrm{ml}$ scintillation fluid (Aqualuma plus, J. T. Baker Chemicals B.V., Deventer, The Netherlands). The percentage of lysis was expressed as the percentage of radioactivity released from labelled bacteria into the supernate. Also, after various time intervals, samples were removed from the mixture and tenfold serial dilutions in PBS were made and plated on Brain Heart Infusion Agar (Difco). After $18 \mathrm{~h}$ incubation at $37^{\circ} \mathrm{C}$, the number of bacteria present in the mixture was measured.

Trichloroacetic acid (TCA) procedure. The extent of degradation of DNA was measured with TCA. An equal volume of tested samples and cold $10 \%(\mathrm{w} / \mathrm{v}) \mathrm{TCA}$ was placed at $4{ }^{\circ} \mathrm{C}$. After $30 \mathrm{~min} 0.2 \mathrm{ml} 1 \%$ bovine serum albumin was added as a carrier. After $15 \mathrm{~min}$ the precipitate was centrifuged and the radioactivity in the supernate and sediment was counted.

Plasmid DNA isolation. Escherichia coli was incubated in serum. At various time intervals the mixtures were centrifuged at $12000 \mathrm{~g}$ and the sediment resuspended in $2 \mathrm{ml}$ PBS. Both the sediments and supernates were transferred to Eppendorf tubes (Eppendorf, Sarstedt, FRG). Plasmid DNA was isolated from the sediment and the supernatant fraction by the rapid alkaline extraction procedure described by Birnboim \& Doly (1979); in this study most plasmid DNA was found in the $12000 \mathrm{~g}$ sediment. Isolated plasmid DNA was dissolved in $100 \mu \mathrm{l}$ distilled water; $10 \mu \mathrm{l}$ was used for measurement of radioactivity; $50 \mu \mathrm{l}$ for gel electrophoresis and $40 \mu \mathrm{l}$ for transformation studies.

Isolation of chromosomal DNA. After incubation of E. coli $\mathrm{PC} 2166(\mathrm{R} 1030)$ in serum at time zero and various intervals thereafter, chromosomal DNA was isolated according to the method of Cosloy \& Oishi (1973). Isolated chromosomal DNA was dissolved in an appropriate volume of $1 / 10$ strength standard saline citrate $(15 \mathrm{~mm}-\mathrm{NaCl}-$ $1.5 \mathrm{~mm}-\mathrm{Na}_{3}$-citrate) (final concentration of DNA, $100-400 \mu \mathrm{g} \mathrm{ml}^{-1}$ ) and kept at $4{ }^{\circ} \mathrm{C}$. Part of the chromosomal DNA $(50 \mu \mathrm{l})$ was used for gel electrophoresis and another portion for transformation studies.

Agarose gel electrophoresis. Plasmid DNA and chromosomal DNA isolated from bacteria after bacteriolysis in serum was visualized in gel by agarose gel electrophoresis. Electrophoresis was carried out in horizontal slab gels (gel dimensions $14.5 \times 27 \times 3 \mathrm{~mm}$, with 16 slots), containing $0.6 \%$ agarose (Agarose type IV, Sigma) dissolved in electrophoresis buffer $\left(40 \mathrm{~mm}\right.$-Tris, $20 \mathrm{~mm}$-sodium acetate. $3 \mathrm{H}_{2} \mathrm{O}, 2 \mathrm{~mm}$-EDTA adjusted to pH $7 \cdot 8$ with acetic acid). Both agarose and electrophoresis buffer contained ethidium bromide in a final concentration of $2 \mu \mathrm{g} \mathrm{ml}^{-1}$. Electrophoresis was performed either for $4 \mathrm{~h}$ at $30 \mathrm{~mA}$ or overnight at $12 \mathrm{~mA}$ and gels were photographed under UV light $(360 \mathrm{~nm})$ using Polaroid type film (Kodak 667) with an orange 22 filter.

Transformation by chromosomal DNA. Escherichia coli AM1095 $\left(\mathrm{Rec}^{+} \mathrm{Leu}^{-}\right)$was transformed by chromosomal DNA isolated from $E$. coli PC2166(RSF1030). The procedure of transformation by chromosomal DNA was described by Bergmans et al. (1981).

Transformation by plasmid DNA. Part of the isolated plasmid DNA suspension was used for transformation studies. The procedure was a modification of the method described by Bergmans et al. (1981). Escherichia coli K12C600 was used as an acceptor strain. A portion $(0.3 \mathrm{ml})$ of competent cells were mixed gently in glass tubes with $0.1 \mathrm{ml}$ plasmid DNA. After $45 \mathrm{~min}$ incubation at $0{ }^{\circ} \mathrm{C}$ the mixture was treated for $6 \mathrm{~min}$ at $42{ }^{\circ} \mathrm{C}$ and afterwards it was chilled again for $30 \mathrm{~min}$ at $0{ }^{\circ} \mathrm{C}$.

A mixture of competent cells and plasmid DNA was diluted 10 times with L-broth $(1 \%$ Bactotryptone, $0.5 \%$ yeast extract, and $0.5 \% \mathrm{NaCl}$ in distilled water) and incubated for $60-120 \mathrm{~min}$ at $37{ }^{\circ} \mathrm{C}$ under aeration. After centrifugation at $2000 \mathrm{~g}$ for $10 \mathrm{~min}$ the cell pellet was dissolved in $1 \mathrm{ml} \mathrm{L}$-broth and $0.2 \mathrm{ml}$ samples were plated on solid media containing ampicillin $\left(40 \mathrm{mg} \mathrm{ml}^{-1}\right)$. Competent $E$. coli $\mathrm{K} 12-\mathrm{C} 600$ which was not subject to 
transformation served as a control. After $18 \mathrm{~h}$ growth at $37^{\circ} \mathrm{C}$ viable colonies (transformants) were counted. Incubation of isolated plasmid and chromosomal DNA in serum. Plasmid and chromosomal DNA isolated from $E$. coli $\mathrm{PC} 2166\left(\mathrm{RSF} 1030\right.$ ) were incubated in $20 \%$ human pooled serum at $37^{\circ} \mathrm{C}$. After various time intervals, samples were removed and placed in ice. These samples were treated with phenol and DNA was precipitated with ethanol and dissolved in distilled water. Plasmid DNA and chromosomal DNA were visualized in gels by the use of agarose gel electrophoresis.

\section{RESULTS}

\section{Release of radioactivity from chromosomal and plasmid DNA}

The incubation of $\left[{ }^{3} \mathrm{H}\right]$ thymidine labelled $E$. coli PC2166(RSF1030) and AM1281(pBR322) harbouring a small plasmid $\left(2.65 \times 10^{6}\right.$ and $\left.5.5 \times 10^{6}\right)$ in $20 \%(\mathrm{v} / \mathrm{v})$ pooled human serum resulted in release of radioactivity from the bacteria into the medium. About $85 \%$ of the total radioactivity was released after $1 \mathrm{~h}$. More than $99.99 \%$ of the bacteria were killed after $15 \mathrm{~min}$ exposure to $20 \%(\mathrm{v} / \mathrm{v})$ pooled human serum. Bacterial killing proceeded more rapidly than the release of radiolabelled material from the bacteria. An obvious question was whether the released radioactivity resulted from the degradation of both chromosomal and plasmid DNA. Chromosomal and plasmid DNA were isolated and the amount of radioactivity with either fraction determined. Virtually, no decrease in plasmid DNA-associated radioactivity in the sediment was observed (Fig. 1) indicating that essentially no degradation of plasmid DNA occurred. To study the extent of degradation of chromosomal DNA, the mixture was treated with cold $10 \%$ TCA after incubation in serum. This treatment permits the distinction between small DNA fragments of less than 12-15 nucleotides and larger DNA fragments (Cleaver \& Boyer, 1972). With up to $2 \mathrm{~h}$ incubation in serum, about $95 \%$ of the radioactivity remained acid precipitable. However, after $2 \mathrm{~h}$ a rapid increase in the amount of radioactivity in the TCA soluble fraction could be measured. After $240 \mathrm{~min}$ of incubation about $60 \%$ of the total radioactivity was acid soluble (data not shown).

Transformation with plasmid DNA and chromosomal DNA after lysis of the bacteria in serum

To study the effect of serum on the transformability of plasmid DNA and chromosomal DNA, plasmid DNA was isolated from E.coli PC2166(RSF1030) and E.coli AM1281(pBR322) and chromosomal DNA from E. coli PC2166(RSF1030) after these bacteria had been incubated in serum. Isolated DNA was then incubated with competent bacteria. Serum did not affect transformation by plasmid DNA but rapidly affected that by chromosomal DNA (Table 1). Since plasmids RSF1020 and pBR322 have a molecular weight of only 2.6-5.5 $\times 10^{6}$ it was of

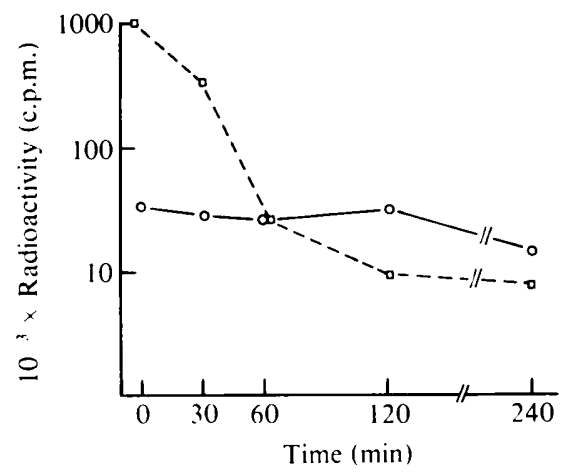

Fig. 1. The effect of serum on chromosomal and plasmid DNA as measured by DNA associated radioactivity. $\left[{ }^{3} \mathrm{H}\right]$ Thymidine labelled $E$. coli $\mathrm{PC} 2166(\mathrm{RSF} 1030)$ were incubated in $20 \%(\mathrm{v} / \mathrm{v})$ human serum. After the indicated time intervals, mixtures were centrifuged at $12000 \mathrm{~g}$ for $10 \mathrm{~min}$. Chromosomal and plasmid DNA were isolated from the resulting sediments and radioactivity, expressed in c.p.m., associated with both fractions was measured. Radioactivity associated with chromosomal DNA $(\square)$, radioactivity associated with plasmid DNA (O). 


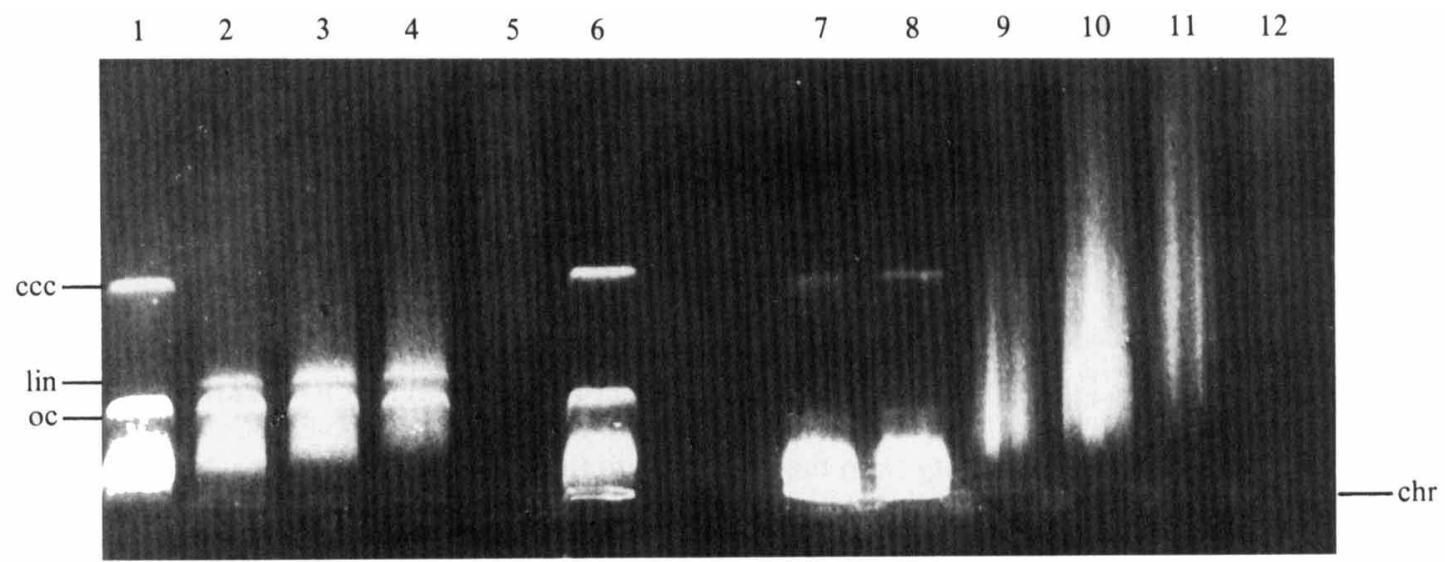

Fig. 2. The effect of serum on chromosomal and plasmid DNA as visualized by agar gel electrophoresis. Chromosomal and plasmid DNA were incubated in $20 \%(\mathrm{v} / \mathrm{v})$ human serum. After various time intervals DNA was electrophoresed on $0.6 \%$ agarose gel dissolved in electrophoresis buffer ( $40 \mathrm{~mm}$-Tris, $20 \mathrm{~mm}$-sodium acetate $3 \mathrm{H}_{2} \mathrm{O}, 2 \mathrm{~mm}$-EDTA) for $18 \mathrm{~h}$ at $12 \mathrm{~mA}$ at $20^{\circ} \mathrm{C}$. Tracks 1 to 5 show plasmid DNA after $0,30,60,120$, and 240 min incubation in serum; track 6 , control plasmid DNA; track 7, control chromosomal DNA; tracks 8 to 12 show chromosomal DNA after $0,30,60,120$, and $240 \mathrm{~min}$ incubation in serum. Abbreviations: chr, chromosomal DNA; ccc, covalently closed circular DNA; oc, open circular DNA; lin, linear plasmid DNA.

Table 1. Transformations with plasmid DNA isolated from the following E. coli strains: PC2166(RSF1030), AM1281(pBR322), PC2166(R144), and the transformation with chromosomal DNA isolated from E. coli PC2166(RSF1030) after incubation of these strains in $20 \%$ human serum

\begin{tabular}{rcccc} 
Time & $\overbrace{\text { Plasmid DNA }}$ & \multicolumn{4}{c}{ Number of transformants } \\
$($ min $)$ & $\overbrace{\text { RSF1030 }}^{\text {pBR322 }}$ & R144 & Chromosomal DNA \\
0 & $55 \times 10^{4}$ & $21 \times 10^{4}$ & 71 & 172 \\
60 & $60 \times 10^{4}$ & $20 \times 10^{4}$ & 7 & 92 \\
120 & $63 \times 10^{4}$ & $16 \times 10^{4}$ & 0 & 40 \\
240 & $59 \times 10^{4}$ & $19 \times 10^{4}$ & 0 & 3
\end{tabular}

interest to study the effect of incubation in serum of E. coli PC2166(R144) with a plasmid of molecular weight $65 \times 10^{6}$. A decrease in the number of transformants was observed after $1 \mathrm{~h}$ incubation of strain PC2166(R144) in serum, indicating that this large plasmid was degraded. In addition, frequency of transformation by the large-size plasmids was much lower than that by the small-size plasmids (Table 1).

\section{Agarose gel electrophoresis of plasmid and chromosomal DNA}

The absence of degradation of small plasmid DNA and the rapid breakdown of chromosomal DNA that occurred after incubation of E. coli PC2166(RSF1030) in serum could be visualized by agarose gel electrophoresis. After various incubation times, the isolated plasmid and chromosomal DNA fractions were subjected to electrophoresis on an agarose gel. Plasmid DNA bands could easily be visualized and were present up to $4 \mathrm{~h}$ incubation of bacteria in serum. In contrast, the chromosomal DNA bands could be visualized only up to $60 \mathrm{~min}$ of incubation. After this time chromosomal DNA bands become smaller and less intense. After $120 \mathrm{~min}$ a large 'smear' of DNA fragments could be seen, indicating that breakdown of DNA had occurred. 
Also, when isolated DNA was incubated directly in serum, chromosomal DNA was degraded much faster than plasmid DNA. The process of degradation of chromosomal DNA was already apparent after 30 min of incubation in serum (Fig. 2). Degradation of plasmid DNA proceeded more slowly than degradation of chromosomal DNA. After $30 \mathrm{~min}$ of incubation of plasmid DNA in serum, the covalently closed circular form of DNA disappeared. The open circular form of DNA remained visible up to $4 \mathrm{~h}$ incubation.

\section{DISCUSSION}

Killing of serum-sensitive $E$. coli strains is a very rapid process - within minutes over $90 \%$ of all bacterial cells are killed. The attack by the complement system on the cell envelope leads to irreversible loss of permeability control and breakdown of intracellular components. Leakage of low molecular weight substances and spillage of ribosomes occurs (Glynn, 1969; Melching \& Vas, 1971). DNA is also released as was measured by the increase of radioactivity in the medium. The release of radioactive material from the bacterium proceeded at a slower rate than the rate of killing, but completely paralleled the bactericidal activity of serum. Therefore, measurement of release of radioactivity during incubation of radiolabelled bacteria in serum can be used as a measure for the bactericidal activity of serum (Friedlander, 1975).

Under the labelling conditions used, essentially all the radioactivity is found in DNA. Therefore, the release of radioactivity into the medium can be taken as a measure of the release of DNA or DNA components. After centrifugation $(12000 \mathrm{~g})$ most of the plasmid DNA was found in the sediment. This fraction mainly contained large bacterial fragments, such as cell envelope components. It appears therefore that the plasmid DNA remains associated with cell wall material.

Our conclusion that the small-size plasmid DNA remained intact up till $4 \mathrm{~h}$ of incubation in serum was based on three different observations: (i) plasmid DNA could easily be sedimented by centrifugation at $12000 \mathrm{~g}$; (ii) characteristic plasmid DNA bands could be observed throughout the incubation period by agarose gel electrophoresis, and (iii) with the isolated plasmid DNA competent acceptor cells could be transformed at a constant frequency.

The much faster degradation of chromosomal DNA (as compared to the plasmid DNA) was also clearly seen when the 'naked' small plasmid DNA and the chromosomal DNA were incubated in serum.

Little is known about the degradation of DNA in serum. Serum has been shown to possess endoDNAase activity (Conolly et al., 1962a,b; Love \& Hewitt, 1979; Melgar \& Goldthwait, 1968; Wroblewski \& Bodansky, 1950). This activity is probably due to a DNAase I enzyme, which shows nearly identical physical and enzymic characteristics with pancreatic DNAase (Love \& Hewitt, 1979); the activities were demonstrated to be endoDNAases. In general, the degradation of double stranded DNA can occur either by a predominantly single-hit mechanism in which both strands are cleaved during one encounter with the enzyme (DNAase II) or by a double-hit mechanism in which the enzyme (DNAase I) cleaves only one strand per encounter. In the case of the double-hit mechanism, only one strand at a time is broken, giving rise to a nick; hence a second distinct enzymic cleavage must occur in the same region of the DNA to cause chain separation. While single-hit kinetics was demonstrated by the rapid formation of double strand breaks, double-hit kinetics was associated with a lag time (Melgar \& Goldthwait, 1968; Schumaker et al., 1956; Thomas, 1956). This may be a possible explanation for the fact that much more time is needed for scission of both strands in plasmid DNA with low molecular weight, as opposed to faster formation of double strand breaks in chromosomal DNA and in plasmid DNA of higher molecular weight. Paoletti et al. (1971) have found that the higher the molecular weight of the closed circular DNA the greater the chance that DNA is degraded. It is also possible that nucleic acid of the cell can escape the action of nucleases by being physically inaccessible to them. Such a situation may arise when the nucleic acid is physically enveloped by or bonded to structures such as histones or other basic proteins that would not permit the active sites of the enzymes to have access to the nucleic acids. 
We can only speculate about the implication and the possible clinical relevance of our findings. It is possible that the resistance to breakdown of small-size plasmid DNA molecules carrying genes coding antibiotic resistance contribute to the increased number of resistant micro-organisms. However, it is still not known whether the transformation of Gram-negative bacilli by plasmid DNA occurs in vivo, and many more studies are needed to assess its clinical relevance.

We thank Mrs M. A. A. J. Beens-Dekkers and Mrs G. M. Vleugel-Klarenbeek for the excellent technical assistance and Mrs E. M. Zuideweg for performing the assays of chromosomal transformation. We are indebted to Miss Y. M. Joseph for her secretarial assistance in the preparation of the manuscript.

\section{REFERENCES}

Bergmans, H. E. N., Van Die, J. M. \& Hoekstra, W. P. M. (1981). Transformation in Escherichia coli: stages in the process. Journal of Bacteriology 146, 564-570.

BIRnBoim, H. C. \& Doly, J. (1979). A rapid alkaline extraction procedure for screening recombinant plasmid DNA. Nucleic Acids Research 7, 1513-1523.

Bladen, H. A., Evans, R. T. \& Mergenhagen, S. E. (1966). Lesions in Escherichia coli membranes after action of antibody and complement. Journal of Bacteriology 91, 2377-2381.

Cleaver, J. E. \& Boyer, H. W. (1972). Solubility and dialysis limits of DNA oligonucleotides. Biochimica et biophysica acta 262, 116-124.

Conolly, J. H., Herriot, R. M. \& Gupta, S. (1962a). Deoxyribonuclease in human blood and platelets. British Journal of Experimental Pathology 43, 392401.

Conolly, J. H., Herriot, R. M. \& Gupta, S. (1962b). Ribonuclease in normal and uraemic human blood. British Journal of Experimental Pathology 43, 402 408.

CosLoY, S. D. \& OISHI, M. (1973). The nature of the transformation process in Escherichia coli K12. Molecular and General Genetics 124, 1-10.

Feingold, D. S., Goldman, J. N. \& Kuritz, H. M. $(1968 a)$. Locus of the action of serum and the role of lysozyme in the serum bactericidal reaction. Journal of Bacteriology 96, 2118-2126.

Feingold, D. S., Goldman, J. N. \& Kuritz, H. M. $(1968 b)$. Locus of the lethal event in the serum bactericidal reaction. Journal of Bacteriology 96, 2127-2131.

Frank, M. M. (1979). The complement system in host defense and inflammation. Reviews of Infectious Diseases 1, 483-501.

Friedlander, A. M. (1975). DNA release as a direct measure of microbial killing. I. Serum bactericidal activity. Journal of Immunology 115, 1404-1408.
GlYNN, A. A. (1969). The complement lysozyme sequence in immune bacteriolysis. Immunology 16, 463-471.

Love, J. D. \& HewITT, R. R. (1979). The relationship between human serum and human pancreatic DNase I. Journal of Biological Chemistry 254, 12588 12594.

Melching, L. \& VAS, S. J. (1971). Effect of serum components on Gram-negative bacteria during bactericidal reactions. Infection and Immunity 3, $107-$ 115.

Melgar, E. \& Goldthwait, D. A. (1968). Deoxyribonucleic acid nucleases. I. The use of a new method to observe the kinetics of deoxyribonucleic acid, degradation by deoxyribonuclease I, deoxyribonuclease II, and Escherichia coli endonuclease I. Journal of Biological Chemistry 243, 4401-4408.

Paoletti, C., Le PecQ, J. B. \& Lehman, I. R. (1971). The use of ethidium bromide circular DNA complexes for the fluorometric analysis of breakage and joining DNA. Journal of Molecular Biology 55, 75100.

Schumaker, V. N., Richards, E. G. \& Schachman, H. K. (1956). A study of kinetics of the enzymatic digestion of deoxyribonucleic acid. Journal of the American Chemical Society 78, 4230-4236.

SpITzNaGel, J. K. \& Wilson, L. A. (1966). Normal serum cytotoxicity for $\mathbf{P}^{32}$-labelled smooth Enterobacteriaceae. I. Loss of label death and ultrastructural damage. Journal of Bacteriology 91, 393-400.

Thомas, C. A., JR. (1956). The enzymatic degradation of deoxyribose nucleic acid. Journal of the American Chemical Society 78, 1861-1868.

Wroblewski, F. \& Bodansky, O. (1950). Presence of deoxyribonuclease activity in human serum. Proceedings of the Royal Society of Experimental Biology and Medicine 74, 443-445. 